\title{
Ants as Vectors of Bacteria in Hospital Environments
}

\author{
Bruna Rafaela Machado Oliveira ${ }^{1}$, Luciano Ferreira de Sousa ${ }^{1}$, Raquel Chalá Soares ${ }^{2}$, \\ Thiago César Nascimento ${ }^{3}$, Marcelo Silva Madureira ${ }^{1}$, Jorge Luiz Fortuna ${ }^{1, *}$ \\ ${ }^{1}$ Universidade do Estado da Bahia, UNEB, Campus X, Teixeira de Freitas, Bahia, Brazil \\ ${ }^{2}$ Commission for the Control of Hospital-Acquired Infections, Hospital Municipal, Teixeira de Freitas, Bahia, Brazil \\ ${ }^{3}$ Universidade Federal de Juiz de Fora, UFJF, Juiz de Fora, Brazil
}

\begin{abstract}
Ants in hospital environments may carry pathogenic microorganisms that cause hospital-acquired infections (HAIs), developing resistance to antimicrobials and therefore representing a public health hazard. HAIs increase mortality rates, as a constant threat in the spread of multi-resistant bacteria. This study isolated and identified pathogenic bacteria in ants captured in a hospital in Brazil. We also identified the main genera of ants in these environments. Ants were attracted using protein and carbohydrate traps. A group of five ants was considered a sample. Microbiological analysis included the isolation of Escherichia coli and other enterobacteria and staphylococci. Susceptibility was tested against vancomycin, cefoxitin, oxacillin, and chloramphenicol. The results of resistance to chloramphenicol assays revealed the presence of resistant Enterobacteriaceae (E. coli), resistant isolates of Citrobacter feundii, Enterobacter spp., Klebsiella spp., and Klebsiella oxytoca, and susceptible Hafnia spp., and Yersinia enterocolitica isolates. For vancomycin, oxacillin, and cefoxitin, the bacteria included resistant and sensitive coagulase-negative Staphylococcus spp. and coagulase-positive $S$. aureus CP. The ant genera identified were Pheidole, Crematogaster, Linepithema, and the species Tapinoma melanocephalum. Ants in hospital environments may carry significant numbers of bacteria resistant to the antimicrobials used. This highlights the risk these bacteria pose in such settings, especially to intensive care patients, who usually are immunodepleted.
\end{abstract}

Keywords Antimicrobial, Hospital-acquired infection, Resistant bacteria

\section{Introduction}

Urbanization processes pose issues such as inordinate population growth, water contamination, and the difficulty to implement sanitary control measures. Such scenario promotes the dissemination of arthropods and therefore of the diseases they may carry. For this reason, these animals pose some of the most important hazards to quality of life, standing as a growing concern [1-5].

More specifically, the presence of ants in hospital environments is a serious health problem. Several ant species act as mechanical vectors to pathogenic microorganisms, which points to the importance of research on the transport of pathogens associated with ants in the development of measures to reduce the prevalence of hospital-acquired infections (HAIs), decrease associated mortality, and optimize healthcare budgets.

Like other social arthropods, ants are attracted by foods or even medical drugs, especially those containing sugar. Ants have impressive mobility features, reaching speeds of

* Corresponding author:

jfortuna@uneb.br (Jorge Luiz Fortuna)

Published online at http://journal.sapub.org/microbiology

Copyright (C) 2017 Scientific \& Academic Publishing. All Rights Reserved
$3 \mathrm{~cm} / \mathrm{s}$. This advantage grants these insects access to several environments in an hospital, carrying pathogenic microorganisms that pose potential threats and may be associated with HAIs [6].

Importantly, the social organization of ants is another factor that induces workers to roam around several hospital environments. In this process these insects may acquire bacteria in potentially contaminated environments like bathrooms, reception desks, and wards, at which point they begin to carry these microorganisms to restricted access settings, such as sterilization rooms, laboratories, nurseries, and operating theatres. The presence of pathogenic bacteria in the tegument of worker ants foraging in essentially any hospital environment qualifies these insects as potentially important agents in the spread of infectious diseases in healthcare facilities [5].

HAIs include any infection a patient develops after admission that manifests during this period or even after discharge, as long as the disease may be associated with the inpatient treatment period or medical procedures carried out then [7]. According to a HAI control survey carried out by Brazil's Sanitary Surveillance Agency (ANVISA), the rate of these infections in the country stands at $9.0 \%$ in the country, though in some healthcare organizations this value has been found to be much higher, reaching impressive 
$88.23 \%$ [8].

In view of the above, healthcare staff has to be aware of the need for controlling and mapping these insects' habits as a means to control HAIs [9], whose main consequences are increased morbidity and mortality rates, and higher costs associated with longer inpatient treatments. Moreover, HAIs stand as a constant threat in the spread of multi-resistant bacteria [10]. This highlights the need for studies on this topic as a tool in the surveillance of infestation hotspots and the detection of resulting microbiological contamination. Such research is also important in the design of more efficacious insect control methods, which indirectly help reduce HAI prevalence.

Aiming to contribute to the knowledge about ants in urban environments, especially hospitals, the present study identified the pathogenic bacteria (enterobacteria and staphylococci) isolated from ants captured in hospital settings, and tested the resistance of these pathogens to selected antibiotics. We also identified the genera of these ants, and discuss the issues associated with their presence in healthcare environments as a key factor in the development of ant control strategies.

\section{Materials and Methods}

\subsection{Collection of Ants}

Ants were collected in 11 different environments in the Municipal Hospital of Teixeira de Freitas, state of Bahia, Brazil, namely: (i) the intensive care unit (ICU), (ii) the semi-intensive care unit, (iii) food preparation facilities, (iv) the social service office, (v) the emergency room, (vi) the operating theatre, (vii) a nurse station, (viii) ward 107 (medical care), (ix) ward 202 (surgery), (x) ward 208 (orthopaedics), and (xi) the food pantry.

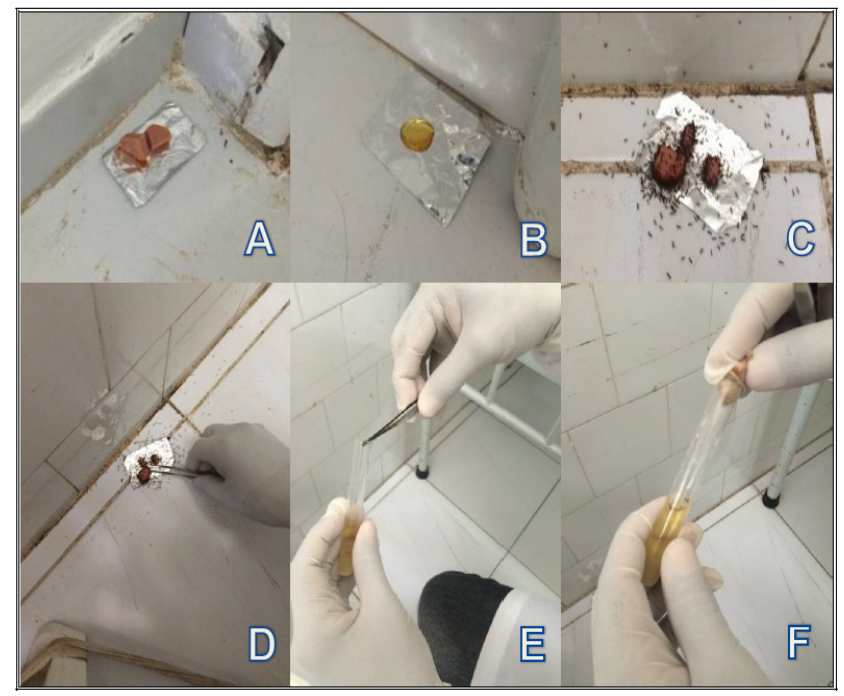

Figure 1. (A) protein bait (sausage) and (B) carbohydrate (honey) baits used to capture ants in a hospital. (C) bait with ants. (D) Collection of ants with tweezers. (E) Ant placed in a test tube with BHI broth. (F) Five ants placed in each tube
Collections took place twice a day, in the morning and early evening in December 2014 and March, May, and August 2015, representing eight collection efforts. In total, 256 protein and carbohydrate traps were used, 128 of each bait. Honey and wiener sausages were used as carbohydrate and protein baits, respectively. Traps were left in each environment for $40 \mathrm{~min}$. Ants were carefully picked with sterilized tweezers and placed in test tubes containing Brain Heart Infusion (BHI) broth. Five ants were placed in each tube, which was labelled identifying the hospital environment of origin (Figure 1). The operator wore sterilized gloves throughout the collection effort [11].

The tubes were then transferred to thermally insulated boxes containing ice and transported to the Laboratory of Microbiology, Universidade do Estado da Bahia (UNEB), where the microbiological analyses were conducted. The identification of ants was carried out in the Laboratory of Zoology, UNEB.

\subsection{Microbiological Analyses}

The tubes containing ants in BHI broth were incubated at $35^{\circ} \mathrm{C}$ for $24 \mathrm{~h}$. Contents with evidence of bacterial growth were seeded on Petri dishes with specific culture media (MacConkey Agar, MCA, for Escherichia coli and other enterobacteria; Mannitol Salt Agar, MSA, for Staphylococcus spp.). Dishes were incubated at $35^{\circ} \mathrm{C}$ for $24 \mathrm{~h}[5,11-13]$.

Typical E. coli colonies and those of other enterobacteria were analysed according to biochemical assays like indole, methyl red, Voges-Proskauer, and citrate (IMViC) to identify and confirm bacteria to species level. Typical Staphylococcus spp. colonies were submitted to the catalase and coagulase assay and to a novobiocin-resistance assay to differentiate Staphylococcus epidermidis and Staphylococcus saprophyticus.

\subsection{Resistance to Antimicrobials}

The species identified were submitted to antimicrobial resistance assays according to the disk diffusion method [15, $16]$.

Colonies of each isolate were used to prepare one bacterial suspension with turbidity adjusted to 0.5 MacFarland. Seeding was carried out in Mueller-Hinton Agar (MHA). Oxacillin, cefoxitin, and vancomycin disks were used to evaluate resistance of the isolates of coagulase-positive (CP) Staphylococcus aureus, coagulase-negative (CN) Staphylococcus, S. saprophyticus, and S. epidermidis. One chloramphenicol disk was used to test $E$. coli and other enterobacteria.

\subsection{Identification of Ants}

Ants were characterized to genus level using identification keys in Baccaro et al. [17]. Ant species were identified using the keys available in specialized websites [18]. 


\section{Results and Discussion}

Of the 256 traps laid, $12(4.7 \%)$ attracted ants (eight of which, or $66.7 \%$, with protein and four, or $33.3 \%$, with carbohydrate baits). In total, 60 individuals were captured. Considering all the eight collection efforts, we caught ants only in three (37.5\%), namely in the afternoon in December 2014, in the morning in March 2015, and in the afternoon in August 2015.

The low number of individuals collected may be explained in view of the fact that half the traps were laid in autumn and winter. A similar finding was observed by Couceiro [19], who collected ants in spring and summer, while only 44 were captured in autumn and winter. Also, the hospital surveyed in the present study had gone through a series of pest control procedures, which prevented more frequent collection efforts. However, insect control was carried out with sulfluramid gel, a slow-release pest control agent, so we managed to collect ants in the environments cited before they actually reached nests.

Of the 11 environments surveyed, ants were captured in seven $(63.6 \%)$, namely the ICU, semi-intensive unit, food preparation facilities, emergency room, ward 107 (medical care), ward 202 (surgery), and ward 208 (orthopaedics).

The highest number of ants was captured in the evening. Collections were successful in both morning and evening in ward 107 (medical care) and ward 202 (surgery) (Table 1).

Of special significance is the fact that resistant bacteria were isolated from ants collected in the ICU, the semi-intensive care unit, ward 107 (medical care), and ward 208 (orthopaedics). This points to the potential dangers of HAIs, since immunodepleted patients are often treated in such hospital environments [20].

Four ant genera were identified. The genus Pheidole was captured in seven $(58.3 \%)$ traps (five with protein, two with carbohydrate baits). Crematogaster was found in two (16.7\%) traps (one with protein, one with carbohydrate), the species Tapinoma melanocephalum was captured in two (16.7\%) carbohydrate traps, and Linepithema was found in one $(8.3 \%)$ protein trap.

Of the 12 ant samples analysed, ten $(83.3 \%)$ carried pathogenic enterobacteria and staphylococci. The two samples $(16.7 \%)$ that did not carry bacteria were collected in the ICU and Ward 208.

Table 1. Pathogenic bacteria isolated and identified from ants captured in hospital environments using protein and carbohydrate traps. Susceptibility of strains to selected antibiotics is shown

\begin{tabular}{|c|c|c|c|c|c|c|c|c|c|}
\hline \multirow{2}{*}{ Environment $^{1}$} & \multirow{2}{*}{ Trap $^{2}$} & \multirow{2}{*}{ Time $^{3}$} & \multirow{2}{*}{$\begin{array}{c}\text { Isolated } \\
\text { staphylococci }^{4}\end{array}$} & \multicolumn{3}{|c|}{ Susceptibility $^{5}$} & \multirow{2}{*}{$\begin{array}{c}\text { Isolated } \\
\text { enterobacteria }\end{array}$} & \multirow{2}{*}{$\frac{\text { Susceptibility }^{\mathbf{5}}}{\text { CLO }}$} & \multirow{2}{*}{$\begin{array}{c}\text { Identified ant } \\
\text { species }\end{array}$} \\
\hline & & & & VAN & CFO & OXA & & & \\
\hline \multirow{3}{*}{ ICU } & \multirow{3}{*}{$\mathrm{P}$} & \multirow{3}{*}{$\mathrm{E}$} & CN Staphylococcus & S & $\mathrm{R}$ & $\mathrm{R}$ & Escherichia coli & $\mathrm{R}$ & \multirow{3}{*}{ Pheidole spp. } \\
\hline & & & CN Staphylococcus & S & S & S & Citrobacter freundii & $\mathrm{R}$ & \\
\hline & & & S. saprophyticus & $\mathrm{S}$ & $\mathrm{S}$ & $\mathrm{S}$ & Enterobacter spp. & $\mathrm{S}$ & \\
\hline \multirow{3}{*}{$\begin{array}{c}\text { Food } \\
\text { preparation } \\
\text { facilities }\end{array}$} & \multirow{3}{*}{$\mathrm{C}$} & \multirow{3}{*}{$\mathrm{E}$} & \multirow{3}{*}{$\begin{array}{l}\text { CN Staphylococcus } \\
\text { CP S. aureus }\end{array}$} & \multirow{3}{*}{$\begin{array}{l}\mathrm{S} \\
\mathrm{S}\end{array}$} & \multirow{3}{*}{$\begin{array}{l}S \\
S\end{array}$} & \multirow{3}{*}{$\begin{array}{l}\mathrm{S} \\
\mathrm{S}\end{array}$} & Klebsiella spp. & $\mathrm{R}$ & \multirow{3}{*}{$\begin{array}{c}\text { Tapinoma } \\
\text { melanocephalum }\end{array}$} \\
\hline & & & & & & & Citrobacter freundii & $\mathrm{S}$ & \\
\hline & & & & & & & Enterobacter spp. & $\mathrm{S}$ & \\
\hline \multirow{2}{*}{$\begin{array}{l}\text { Semi-intensive } \\
\text { care unit }\end{array}$} & \multirow{2}{*}{$\mathrm{C}$} & \multirow{2}{*}{ M } & CN Staphylococcus & $\mathrm{S}$ & S & S & Hafnia spp. & S & \multirow{2}{*}{$\begin{array}{c}\text { Tapinoma } \\
\text { melanocephalum }\end{array}$} \\
\hline & & & CN Staphylococcus & $\mathrm{R}$ & $\mathrm{S}$ & $\mathrm{R}$ & Klebsiella oxytoca & $\mathrm{R}$ & \\
\hline \multirow{2}{*}{$\begin{array}{l}\text { Emergency } \\
\text { room }\end{array}$} & \multirow{2}{*}{$\mathrm{P}$} & \multirow{2}{*}{ E } & CN Staphylococcus & $\mathrm{R}$ & $\mathrm{S}$ & $\mathrm{R}$ & Citrobacter freundii & S & \multirow{2}{*}{ Pheidole spp. } \\
\hline & & & CN Staphylococcus & $\mathrm{S}$ & $\mathrm{S}$ & $\mathrm{S}$ & Hafnia spp. & $\mathrm{S}$ & \\
\hline \multirow{5}{*}{$\begin{array}{c}\text { Ward } 107 \\
\text { (medical care) }\end{array}$} & \multirow{2}{*}{$\mathrm{P}$} & \multirow{2}{*}{ E } & \multirow{2}{*}{ S. epidermidis } & \multirow{2}{*}{$\mathrm{R}$} & $\mathrm{S}$ & $\mathrm{R}$ & Citrobacter freundii & $\mathrm{S}$ & Linepithema \\
\hline & & & & & s & $\mathrm{K}$ & Enterobacter spp. & S & spp. \\
\hline & $\mathrm{C}$ & $\mathrm{F}$ & CP $S$ aureus & $\mathrm{S}$ & $\mathrm{S}$ & $\mathrm{S}$ & Citrobacter freundii & $\mathrm{S}$ & Crematogaster \\
\hline & $\mathrm{C}$ & $\mathrm{E}$ & CPS. aureus & $\mathrm{s}$ & $\mathrm{s}$ & $\mathrm{s}$ & Enterobacter spp. & $\mathrm{S}$ & spp. \\
\hline & $P$ & M & CN Staphylococcus & $\mathrm{S}$ & $\mathrm{S}$ & S & Hafnia spp. & S & Pheidole spp. \\
\hline & P & $F_{2}$ & S. epidermidis & $\mathrm{S}$ & S & S & Citrobacter freundii & S & Crematogaster \\
\hline Ward 202 & $P$ & $\mathrm{E}$ & CN Staphylococcus & $\mathrm{R}$ & $\mathrm{R}$ & $\mathrm{R}$ & Enterobacter spp. & $\mathrm{S}$ & spp. \\
\hline (surgery) & $\mathrm{P}$ & M & CN Staphylococcus & $\mathrm{S}$ & $\mathrm{S}$ & $\mathrm{S}$ & Yersinia enterocolitica & S & Pheidole spp. \\
\hline & & $1 \mathrm{NI}$ & Civ staphytococens & $\mathrm{S}$ & $\mathrm{S}$ & $\mathrm{S}$ & Hafnia spp. & $\mathrm{S}$ & Pnelaole spp. \\
\hline Ward 208 & $\mathrm{P}$ & $\mathrm{E}$ & S. epidermidis & $\mathrm{S}$ & $\mathrm{S}$ & $\mathrm{S}$ & Citrobacter freundii & $\mathrm{R}$ & Pheidole spn \\
\hline (orthopaedics) & & $\mathrm{L}$ & 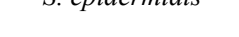 & $\mathrm{S}$ & S & & Enterobacter spp. & $\mathrm{R}$ & \\
\hline
\end{tabular}

${ }^{1} \mathrm{ICU}$ (intensive care unit); ${ }^{2} \mathrm{P}$ (protein), C (carbohydrate); ${ }^{3} \mathrm{E}$ (evening); $\mathrm{M}$ (morning); ${ }^{4} \mathrm{CN}$ (coagulase-negative); $\mathrm{CP}$ (coagulase-positive); ${ }^{5} \mathrm{VAN}$ (vancomycin); CFO (cefoxitin); OXA (oxacillin); CLO (Chloramphenicol); S (susceptible); R (resistant). 
Ants of the Pheidole genus were the most common in this study. The main characteristic of this native species is polygyny, which reduces intercolonial aggression and enables individuals to roam around hospital environments. In this process, these ants acquire pathogenic bacteria, spreading infectious diseases in such settings [5, 21]. Virtually all Pheidole species build their colonies on the ground, under rocks or logs, or underground, forming small hillocks. Also, numerous species of the genus feed exclusively on other insects [22].

Besides a wide geographic distribution, the genus Crematogaster has high species abundance and richness as well as good adaptation competencies at both local and global levels [23]. Such features explain this genus' predominance compared to other Formicidae, and clarify the fact that it was repeatedly captured not only in the present but in other studies as well [24-27].

The ghost ant Tapinoma melanocephalum (Fabricius) is an ubiquitous indoor and outdoor pest. Infestations in homes are restricted to high humidity environments that meet its survival requirements. As a cosmopolitan species introduced in several parts of the globe, T. melanocephalum has spread so efficiently that today it is virtually impossible to establish its actual geographic origins [28]. As a rule, its colonies are build in cramped, unstable surroundings like tussocks of dead grass that has retained some humidity, though stems of plants and holes under debris may also be used for the purpose [29]. In indoor nests, T. melanocephalum colonizes voids on walls or between wardrobes and skirting boards. It also builds nests in plant pots [3]. These characteristics explain the presence of $T$. melanocephalum in the samples collected, since the hospital is surrounded by an open plot of land partially covered with a lawn. Inside the hospital, it is possible that these ants built their colonies between cupboards or furniture in general, and in holes on the wall, as described by Smith and Whitman [30].

The genus Linepithema is native to the Neotropical Region [31]. Except for Linepithema humile (Mayr), the bioecology of the genus has not been clarified. As a rule, these species build their colonies on the ground, heaps of leaves, decayed wood, or under rocks [31]. In addition, $L$. humile has considerable ecological plasticity, feeding on liquids containing sugar [17], which explains its presence in urban and hospital environments where such resources are available.

The genera identified in the present study have been described in previous investigations on the presence of ants in hospital environments in Brazil [5, 6, 14, 32]. The studies cited revealed that ant diversity in Brazilian hospitals is consistently high [33]. Such preference may be explained in view of the affinity some ant species have for surgical instruments and sterilized materials, as demonstrated in a study that showed that some ant species are extremely abundant in hospital environments [34].

Of the 16 staphylococcus strains identified, three (18.75\%) were $S$. aureus. The other $13(81.25 \%)$ were $\mathrm{CN}$ Staphylococcus, of which three $(23.07 \%)$ were $S$. epidermidis and one (7.69\%) was S. saprophyticus. Also, five $(31.25 \%)$ staphylococcus strains were resistant to at least one antimicrobial agent used, while $11 \%$ were susceptible to all drugs (Table 1). All isolates resistant to one of the antimicrobials used were resistant to oxacillin. The importance of this finding lies in the fact that methycilin-resistant Staphylococcus aureus isolates are also resistant to oxacillin.

Notably, CN Staphylococcus is the microorganism most often isolated in HAIs. Research has shown that methycilinresistant CN Staphylococcus increases the risk of morbidity and mortality, and is the main pathogen behind blood infections.

The relevance of CN Staphylococcus as a pathogen was for long ignored, but recent studies have cautioned about the surge in isolates resistant to antibiotics like oxacillin and $\beta$-lactam agents such as penicillin and cefazolin, especially in inpatients. Today, the pathogen has reached considerable importance in the aetiology of HAIs [21, 36]. CN Staphylococcus is the main causal agent of HAIs, mostly in ICU patients [37].

For Pereira and Ueno [38], the isolation of $\mathrm{CN}$ Staphylococcus bears special significance, since it is one of the groups most frequently isolated in HAIs. Besides, $S$. epidermidis has been acknowledged to be the main etiological agent of bacteraemia, postoperative infections, and urinary tract infections. It is also one of the microorganisms that establishes biofilms in medical instruments, which is another indicative of its role in HAIs [39].

The increasing resistance of pathogenic bacteria to antimicrobials has provoked the rise in morbidity and mortality rates in HAIs. The most hazardous pathogenic bacteria are the Gram-negative rods like enterobacteria, apart from Gram-positive microorganisms, such as CP Staphylococcus aureus [40].

Of the 21 enterobacteria strains isolated, seven (33.3\%) were Citrobacter freundii, six (28.6\%) were Enterobacter spp., four (19.0\%) were Hafnia spp., one (4.8\%) was E. coli, one $(4.8 \%)$ Klebsiella spp., one (4.8\%) Klebsiella oxytoca, and one (4.8\%) Yersinia enterocolitica. Also, of these 21 strains, six $(28.6 \%)$ were resistant to chloramphenicol, namely one $E$. coli isolated from ants in the ICU, two $C$. freundii spp. (one from the ICU, one from ward 208, orthopaedics), one Enterobacter spp. from ward 208 (orthopaedics), and one $K$. oxytoca from the semi-intensive care unit (Table 1). These findings agree with previous data, which also revealed the high species diversity of bacteria in hospital environments [6, 27, 32, 38, 41].

Gram-negative bacteria are currently the main agents responsible for HAIs both in long-term inpatients and in those that underwent invasive medical procedures [33]. The contact of patients with these bacteria may become a complicating variable when admittance to hospital is to treat an unrelated disease, as it is the case of immunodepleted individuals, in whom HAIs like gastroenteritis, for instance, may be an extra obstacle in the medical staff's efforts to 
reach homeostasis $[42,43]$. Therefore, the importance of this class of bacteria should never be overlooked in hospital settings. These microorganisms, mainly Klebsiella spp. and Enterobacter sp., evolve to an antibiotic-resistant status quite quickly, causing severe infections [44].

For Tanaka et al. [6], the presence of multi-resistant bacteria isolated from ants in settings like a hospital ward is a key factor in direct disease transmission. More specifically, such finding points to higher risks for HAIs, highlighting the need for pest insect control measures in such environments.

Roughly $10 \%$ of inpatients contract HAIs after an invasive medical procedure or immunosuppressive therapy [45]. The bacteria Enterococcus spp., Staphylococcus aureus, Pseudomonas aeruginosa, Acinetobacter spp., E. coli, Klebsiella spp., and Enterobacter spp. have been highlighted as the main pathogens behind HAIs in these patients. These bacteria were, essentially, the same as the ones isolated in this study. Moura et al. [46] also surveyed two ICUs in a teaching public hospital in the city of Teresina, state of Piauí, Brazil and determined the prevalence of HAIs. Interestingly, $35 \%$ of these infections were caused by Klebsiella spp., $17.9 \%$ by Staphylococcus spp., and $24 \%$ by Pseudomonas spp.

The association of enterobacteria and ants has been reported in Brazilian hospitals, posing risks to inpatients. Enterobacteria are commonly isolated from insects, and are horizontally transmitted. Yet, these pathogenic microorganisms may also be acquired from the environment, which underscores their remarkable spreading and colonizing capabilities [5, 33, 38].

Bacteria carried by ants in hospital environments may be antimicrobial-resistant, which underscores the need for greater awareness in healthcare organizations concerning the prevention of HAIs. In this sense, control measures should be adopted, from simply washing hands to more complex efforts, like the sensible prescription of antimicrobials and the careful planning of pest control applications.

\section{Conclusions}

The results show that the ants captured are possibly working as carriers of pathogenic bacteria. Transmission may take place directly, when ants crawl up a patient's skin, or indirectly, when they run on medical devices. Besides the fact that these ants carry a significant number of clinically important bacteria in hospital settings, another relevant finding was the resistance to selected antimicrobials, which increases the risk of HAIs, especially in ICU inpatients who, in most cases, are immunodepleted.

The great importance of bacteria carried by ants in hospital environments lies in the resistance to antimicrobials they develop, highlighting the need for increased awareness in healthcare organizations as to the adoption of strict prevention measures. Such initiatives may be as simple as washing hands properly and as complex as devising sensible courses of antimicrobials to inpatients or conceiving efficient pest control programmes.

Despite the confirmation that ants carry microorganisms, our results have not afforded to clarify the precise role these insects have in HAIs. Further studies should be conducted to assess the risk of infection in hospital settings potentially colonized by ants.

\section{ACKNOWLEDGEMENTS}

The authors thank Fundação de Amparo à Pesquisa do Estado da Bahia (FAPESB) for the grants given, and to Comissão de Controle de Infecção Hospitalar (CCIH), Hospital Municipal de Teixeira de Freitas, state of Bahia, Brazil, for allowing us to collect ant samples.

\section{REFERENCES}

[1] Bueno O. C., Campos-Farinha, A. E. C., 1998, Formigas Urbanas: Comportamento das espécies que invadem as cidades brasileiras. Revista Vetores \& Pragas, 1, 13-16.

[2] Campos-Farinha, A. E. C, Bueno, O. C., Campos, M. G. C., Kato, L. M., 2002, As formigas urbanas no Brasil: Retrospecto. Arquivos do Instituto Biológico, 64, 129-133.

[3] Freitas, M. R., Teixeira, I. R. V., 2007, A formiga fantasma (Tapinoma Melanocephalum) domina os ambientes hospitalares em Guaxupé, MG, Proc., VII Congresso de Ecologia do Brasil, Sociedade de Ecologia do Brasil, Caxambu, MG, 1-2.

[4] Oliveira, M. F., Campos-Farinha, A. E. C., 2005, Formigas urbanas no município de Maringá, PR, e suas implicações. Arquivos do Instituto Biológico, 72(1), 33-39.

[5] Pesquero, M. A., Elias Filho, J., Carneiro, L. C., Feitosa, S. B., Oliveira, M. A. C., Quintana, R. C., 2008, Formigas em ambiente hospitalar e seu potencial como transmissoras de bactérias, Neotropical Entomology, 37, 4, 472-477.

[6] Tanaka, I. T., Viggiani, A. M. F. S., Person, O. C., 2007, Bactérias veiculadas por formigas em ambiente hospitalar, Arquivos Médicos do ABC, 32(2), 60-63.

[7] Brasil, Agência Nacional de Vigilância Sanitária, Ministério da Saúde, 1998, Portaria $n^{\circ}$ 2.616, de 12 de maio de 1998, ANVISA, Brasilia.

[8] Brasil, Agência Nacional de Vigilância Sanitária, Ministério da Saúde, 2014, Panorama do controle da infecção hospitalar no Brasil: O resultado de 20 anos de ações no país, Avaialble: $<$ http://www.anvisa.gov.br/servicosaude/controle/infectes $\mathrm{h}$ ospitalares_panorama.pdf $>$.

[9] Garcia, F. R. M., Lise, F., 2013, Ants associated with pathogenic microorganisms in brazilian hospitals: attention to a silent vector, Acta Scientiarum Health Sciences, 35(1), 9-14.

[10] Teixeira, M. M., 2007, Formigas como carreadoras de microrganismos no Hospital Escola da Universidade Federal do Triângulo Mineiro Uberaba/MG, MSc Dissertation, Universidade Federal do Triângulo Mineiro, UFTM. 
[11] Carneiro, L. C., Carvalhares, T. T., Pesquero, M. A., Quintana, R. C., Feitosa, S. B., Elias Filho, J., Oliveira, M. A. C., 2008, Identificação de bactérias causadoras de infecção hospitalar e avaliação da tolerância a antibióticos, NewsLab, 86, 106-114.

[12] Fontana, R., Wetler, R. M. C., Aquino, R. S. S., Andrioli, J. L., Queiroz, G. R. G., Ferreira, S. L., Nascimento, I. C., Delabie, J. H. C., 2010, Disseminação de bactérias patogênicas por formigas (Hymenoptera: Formicidae) em dois hospitais do nordeste do Brasil, Neotropical Entomology, 39(4), 655-663.

[13] Pereira, R. S., Ueno, M., 2013, Presença de bactérias resistentes aos antimicrobianos em formigas de ambiente hospitalar, Revista Biociências, 19(2), 83-87.

[14] Santos, P. F., Fonseca, A. R., Sanches, N. M., 2009, Formigas (Hymenoptera: Formicidae) como vetores de bactérias em dois hospitais do município de Divinópolis, estado de Minas Gerais, Revista da Sociedade Brasileira de Medicina Tropical, 42(5), 565-569.

[15] Bauer, A. W., Kirby, W. M. M., Sherris, J. C., Turck, M., 1966, Antibiotic susceptibility testing by a standardized single disk method, American Journal of Clinical Pathology, 45, 493-496.

[16] CLSI, Clinical and Laboratory Standards Institute, 2005, Performance Standards for Antimicrobial Susceptibility Testing, Fifteenth Informational Supplement, Clinical and Laboratory Standards Institute. Wayne, Pennsylvania 19087-1898 USA.

[17] Baccaro, F. B, Feitosa, R. M, Fernandez, F., Fernandes, I. O., Izzo, T. J., Souza, J. L. P., Solar, R. 2015, Guia para Gêneros de Formigas no Brasil, Editora INPA, Manaus.

[18] AntWeb, 2015, Website AntWeb. [Online]. Available: $<$ https://www.antweb.org/>.

[19] Couceiro, R. A. P. M., 2012, Avaliação de formigas como vetor mecânico de micobactérias em hospital especializado na assistência de pacientes de tuberculose do estado de São Paulo, PhD thesis, Faculdade de Saúde Pública, USP.

[20] Sambati, N., Garcia, T. I., Parussulo, L., Pavanelli, M. F., 2016, Formigas como vetores de bactérias em um hospital de médio porte de Campo Mourão, Paraná, SaBios: Revista da Saúde e Biologia, 11(1), 74-79.

[21] Zarzuela, M. F. M, Ribeiro, M. C. C., Campos-Farinha, A. E. C., 2002, Distribuição de formigas urbanas em um hospital da região sudeste do Brasil, Arquivos do Instituto Biológico, 69(1), 85-87.

[22] Wheeler, W. M., 1922, Ants of the American Museum Congo expedition. A contribution to the myrmecology of Africa, Bulletin of the American Museum of Natural History. [Online]. Available:

$<$ http://www.antwiki.org/wiki/images/d/de/Wheeler_1922b. pdf $>$.

[23] Wilson, E. O., 1976, Which are the most prevalent ant genera? Studia Entomologica, 19, 187-200.

[24] Bueno, O. C., Campos-Farinha, A. E. C., 1999, Formigas Urbanas: Estratégias de Controle, Revista Vetores \& Pragas, Ano II, 5, 5-7.

[25] Cintra, P., 2006, Ocorrência de artrópodes em ambientes hospitalares, $\mathrm{PhD}$ thesis, Universidade Estadual Paulista.
[26] Fernández, F., 2003, Introducción a las Hormigas de la Región Neotropical, Instituto de Investigación de Recursos Biológicos Alexander Von Humboldt, Bogota.

[27] Peçanha, M. P., 2000, Formigas como vetor de propagação bacteriana no conjunto hospitalar de Sorocaba, $\mathrm{PhD}$ thesis, UNESP.

[28] Smith, M. R., 1965, House-infesting Ants of the Eastern United States, Their Recognition, Biology, and Economic Importance, USDA-ARS Technical Bulletin 132, USADA-ARS, cidade.

[29] Oster, G. F., Wilson, E. O., 1978, Caste and Ecology in the Social Insects, Princeton University Press, Princeton.

[30] Smith, E. H., Whitman, R. C., 1992, Field Guide to Structural Pests, National Pest Management Association, Dunn Loring.

[31] Bolton, B., Alpert, G., Ward, P. S., Naskrecki, P., 2006, Bolton's Catalogue of Ants of the World: 1758-2005, Harvard University, Cambridge.

[32] Teixeira, M. M., Pelli, A., Santos, V. M., Reis, M. G., 2009, Microbiota associated with tramp ants in a Brazilian University Hospital, Neotropical Entomologyst, 38(4), 537-541.

[33] Moreira, D. D. O., Morais, V., Vieira-Da-Motta, O., Campos-Farinha, A. A. C., Tonhasca Jr., A., 2005, Ants and carriers of antibiotic-resistant bacteria in hospitals, Neotropical Entomology, 34(6), 999-1006.

[34] Eicheler, W., 1990, Health aspects and control of Monomorium pharaonic, in Vander Meer, R. K., Jaffe, K., Cedeño, A. eds., Applied myrmecology: a world perspective, Westview Press, Boulder, pp. 671-675.

[35] Gastmeier, P., Geffers, C., Sohr, D., Schwab, F., Behnke, M., Ruden, H., 2003, Surveillance of nosocomial infections in intensive care units: current data and interpretations, Wiener Klin Wochenschr, 115, 99-103.

[36] Azevedo, P. A. D., 2007, Suscetibilidade à novobiocina na identificação de amostras de Staphylococcus coagulase negativos (SCoN) isolados de hemoculturas, Revista Brasileira de Análises Clínicas, São Paulo, 39(4), 303-304.

[37] Cunha, M. L. R. S., Lopes, C. A. M., 2002, Estudo da produção de $\beta$-lactamase e sensibilidade às drogas em linhagens de estafilococos coagulase-negativos isolados de recém-nascidos, Jornal Brasileiro de Patologia e Medicina Laboratorial, 38(4), 281-290.

[38] Pereira, R. S., Ueno, M., 2008, Formigas como veiculadoras de microrganismos em ambiente hospitalar, Revista da Sociedade Brasileira de Medicina Tropical, 41(5), 492-495.

[39] Dunne, W. M., Mason, J. R. E. O., Kaplan, S. L., 1993, Diffusion of rifampin and vacomycin through a Staphylococcus epidermidis biofilm, Antimicrobial Agents and Chemotherapy, 37, 2522-2526.

[40] Yates, R. R., 2000, Novas estratégias de intervenção para redução da resistência aos antibióticos: surtos de resistência e opções terapêuticas, Chest, 2(1), 24-27.

[41] Fowler, H. G., Bueno, O. C., Sadatsune, T., Montelli, A. C., 1993, Ants as potential vectors of pathogens in Brazilian hospitals in the state of São Paulo, Brazil, Insecta Science Applied, 14, 367-370. 
[42] Fontoura, C. S. M., Cruz, D. O, Londero, L. G., Vieira, R. M., 2006, Avaliação nutricional de paciente critico, Revista Brasileira de Terapia Intensiva, São Paulo, 18(3).

[43] Maica, A. O., Schweigert, I. D., 2008, Avaliação nutricional em pacientes graves, Revista Brasileira de Terapia Intensiva, 20(3).

[44] Ocana, C. A. V., Rocchi, M., Gasparotto, A., Conrero, I., Navarro, M., Factorovich, S., Albrecht, C., Monterisi, A., 2007, Bacteriemia por enterobacterias en adultos en un hospital universitario: análisis de cinco años, Revista Argentina de Microbiología, 39(1).
[45] ANVISA, Agência Nacional de Vigilância Sanitária, 2007, Investigação e Controle de Bactérias Multirresistentes. [Online]. Available: <www.professores.uff.br/jorge/manual_ controle_bacterias.pdf $>$.

[46] Moura, M. E. B., Campelo, S. M. A, Brito, F. C. P., Batista, O. M. A., Araújo, T. M. E., Oliveira, A. D. S., 2007, Infecção Hospitalar: Estudo de Prevalência em um Hospital Publico de Ensino, Revista Brasileira de Enfermagem, 60(4), 416-421. 